\title{
SURFACE ENERGY AND RADIATION \\ BUDGETS IN A STEPPE ECOSYSTEM IN \\ THE UPPER COLUMBIA RIVER GORGE
}

C. D. Whiteman

K. J. Allwine

X. Bian

August 1994

Prepared for

the U.S. Department of Energy

under Contract DE-AC06-76RLO 1830

Pacific Northwest Laboratory

Richland, Washington 99352 


\section{DISCLAIMER}

This report was prepared as an account of work sponsored by an agency of the United States Government. Neither the United States Government nor any agency thereof, nor any of their employees, make any warranty, express or implied, or assumes any legal liability or responsibility for the accuracy, completeness, or usefulness of any information, apparatus, product, or process disclosed, or represents that its use would not infringe privately owned rights. Reference herein to any specific commercial product, process, or service by trade name, trademark, manufacturer, or otherwise does not necessarily constitute or imply its endorsement, recommendation, or favoring by the United States Government or any agency thereof. The views and opinions of authors expressed herein do not necessarily state or reflect those of the United States Government or any agency thereof. 


\section{DISCLAIMER}

Portions of this document may be illegible in electronic image products. Images are produced from the best available original document. 


\section{Summary}

Measurements of radiation and surface energy budget components are presented for a semiarid grassland-steppe ecosystem in the Upper Columbia River Gorge $\left(45^{\circ} 45^{\prime} 25.6^{\prime \prime} \mathrm{N}, 120^{\circ} 01^{\prime} 39.3^{\prime \prime} \mathrm{W}\right.$, $190 \mathrm{~m}$ ) for June 2-27, 1991. Over this period, the ratio of sensible to latent heat flux (the Bowen ratio) averaged 5.0, and mean daily surface energy balance totals were: net radiation, 9.23; ground heat flux, 1.25; latent heat flux, 1.32 ; and sensible heat flux, $6.66 \mathrm{MJ} \mathrm{m}^{-2} \mathrm{~d}^{-1}$, where the mean daily nonradiative fluxes were directed away from the surface, and the mean daily radiative flux was directed toward the surface. On clear days, the site received from 0.71 to 0.76 of the theoretical extraterrestrial solar radiation. Albedo over the 26-d period varied from 0.17 to 0.21 . Daily and daytime average values of the components are summarized, and a plot is presented of the 30 -min average values of all components for the entire period. 



\section{Acknowledgments}

We wish to thank Mr. Clint Krebs for providing access to the experimental site. We appreciate having the opportunity to participate in the Boardman Regional Flux (BRF) Experiment and would like to thank Dr. Chris Doran and other investigators for logistical support. This contribution to the BRF experiment was supported by the U.S. Department of Energy's (DOE) Atmospheric Radiation Measurements (ARM) and Atmospheric Studies in Complex Terrain (ASCOT) programs. Research was supported by DOE under Contract DE-AC06-76RLO 1830 at Pacific Northwest Laboratory. Pacific Northwest Laboratory is operated for DOE by Battelle Memorial Institute. 



\section{Contents}

SUMMARY $\ldots \ldots \ldots \ldots \ldots \ldots \ldots \ldots \ldots \ldots \ldots \ldots \ldots \ldots \ldots \ldots \ldots$

ACKNOWLEDGMENTS $\ldots \ldots \ldots \ldots \ldots \ldots \ldots \ldots \ldots \ldots$

1.0 INTRODUCTION $\ldots \ldots \ldots \ldots \ldots \ldots \ldots \ldots \ldots \ldots \ldots \ldots \ldots \ldots$

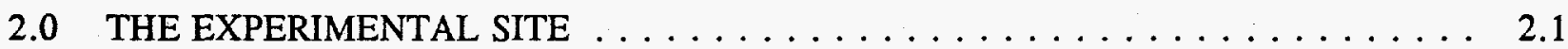

3.0 WEATHER DURING THE EXPERIMENT $\ldots \ldots \ldots \ldots \ldots \ldots \ldots \ldots$

4.0 MEASUREMENTS AND METHODS $\ldots \ldots \ldots \ldots \ldots \ldots \ldots \ldots \ldots$

4.1 RADIATION BUDGET $\ldots \ldots \ldots \ldots \ldots \ldots \ldots \ldots \ldots \ldots \ldots \ldots \ldots$

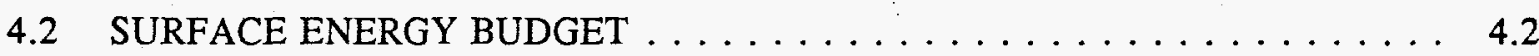

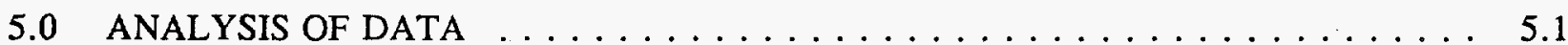

5.1 RADIATION BUDGET TERMS $\ldots \ldots \ldots \ldots \ldots \ldots \ldots \ldots \ldots$

5.1 .1 Extraterrestrial Solar Irradiance $\ldots \ldots \ldots \ldots \ldots \ldots \ldots \ldots . \ldots \ldots$

5.1 .2 Incoming Solar Radiation $\ldots \ldots \ldots \ldots \ldots \ldots \ldots \ldots \ldots \ldots \ldots$

5.1 .3 Reflected Solar Irradiation $\ldots \ldots \ldots \ldots \ldots \ldots \ldots \ldots \ldots$

5.1 .4 Incoming and Outgoing Longwave Radiation . . . . . . . . . . . 5.5

5.1 .5 Net All-wave Radiation $\ldots \ldots \ldots \ldots \ldots \ldots \ldots \ldots$

5.2 SURFACE ENERGY BUDGET TERMS $\ldots \ldots \ldots \ldots \ldots \ldots \ldots$

5.2 .1 Ground Heat Flux . . . . . . . . . . . . . . . 5.6

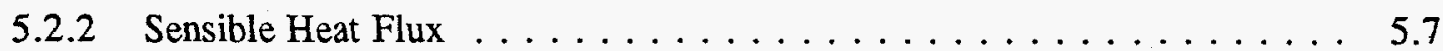

5.2 .3 Latent Heat Flux $\ldots \ldots \ldots \ldots \ldots \ldots \ldots \ldots \ldots \ldots$

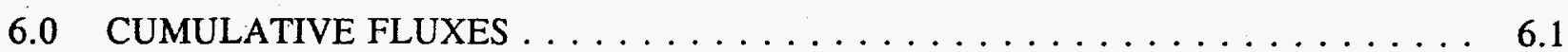

7.0 SUMMARY AND CONCLUSIONS $\ldots \ldots \ldots \ldots \ldots \ldots \ldots$

8.0 REFERENCES $\ldots \ldots \ldots \ldots \ldots \ldots \ldots \ldots \ldots \ldots \ldots \ldots \ldots \ldots \ldots$

APPENDIX A - METHOD FOR ESTIMATING THE SOIL VOLUMETRIC

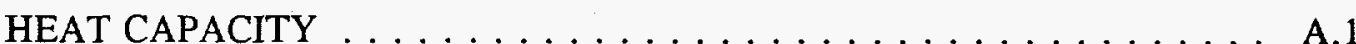




\section{Figures}

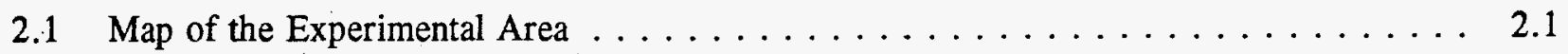

2.2 The Krebs Ranch Site, Looking Toward the Southeast $\ldots \ldots \ldots \ldots \ldots$

3.1 Basic Meteorological Data at Krebs Ranch, Oregon, from June 2 through $27 \ldots 3.1$

5.1 Instantaneous Radiation and Energy Balance Components $\ldots \ldots \ldots \ldots . \ldots \ldots$

6.1 Cumulative Fluxes of Sensible Heat, Latent Heat, Soil Heat, and Net Radiation During the $26-\mathrm{d}$ Period . . . . . . . . . . . . . . . . . . . . 6.1

A.1 The Soil Volumetric Heat Capacity Versus Time During the Experimental Period . . . . A.3

\section{Tables}

4.1 Instruments Used in the Experiments $\ldots \ldots \ldots \ldots \ldots \ldots \ldots \ldots$

5.1 Daily and Daytime Totals $\left(\mathrm{MJ} \mathrm{m}^{-2} \mathrm{~d}^{-1}\right)$ of Radiative and Surface Energy Budget Components at Krebs Ranch, Oregon, as Calculated from 30 -min Averages . . . . . . 5.3

A.1 Soil Sample Analyses $\ldots \ldots \ldots \ldots \ldots \ldots \ldots \ldots \ldots \ldots \ldots \ldots \ldots \ldots$

A.2 Soil Sample Volume Fractions and Volumetric Soil Heat Capacities . . . . . . . . A.2 


\subsection{Introduction}

The Columbia River Gorge is a major east-west valley that cuts through the north-southoriented Cascade Mountain Range of Washington and Oregon. It is an important channel for the transport of low-level Pacific marine air into the continent. In summer, high pressure over the Pacific Ocean and a thermal low in the interior Columbia Basin east of the Cascades produce winds that bring marine air through the gorge from the west. The source of moisture west of the Cascades combined with the westerly flow and the topography of the gorge results in strong gradients in precipitation and other climate elements along the gorge. For example, annual precipitation on the western side of the Cascades at Portland, Oregon, reaches $2,032 \mathrm{~mm}\left(\sim 80 \mathrm{in}\right.$.) $\mathrm{yr}^{-1}$, but annual precipitation attains only about $200 \mathrm{~mm}\left(\sim 8 \mathrm{in}\right.$.) $\mathrm{yr}^{-1}$ in the upper gorge.

A meteorological experiment, called the Boardman Regional Flux (BRF) Experiment, was conducted as part of the U.S. Department of Energy's Atmospheric Radiation Measurements (ARM) program in the Upper Columbia River Gorge near Boardman, Oregon, in June 1991. The experiment investigated the effects of variations in surface moisture and vegetation cover in the upper gorge on mesoscale circulations (Doran et al. 1993). The natural grassland-steppe surface cover in the upper gorge has been modified by large clusters of center-pivot-irrigated agricultural fields, and the proximity of irrigated and natural steppe vegetation allowed an observational and numerical flow modeling study of the effects of vegetation boundaries, surface roughness discontinuities, and surface energy budget discontinuities on the development of mesoscale circulations.

As part of the BRF Experiment, a radiation and surface energy budget station was operated upwind (i.e., to the west) of the main experimental area in a natural steppe ecosystem that was not expected to be influenced by the downwind clusters of irrigated agricultural fields. Unusually complete and detailed measurements of the radiation and surface energy budget components were collected from this station for nearly one month at a location that is expected to be representative of the upper gorge in nonirrigated locations. This paper reports the results of these measurements, which are the first comprehensive measurements available from this area. The results are expected to be of interest to climatologists, boundary layer meteorologists, and climate modelers, among others.

The paper begins with a description of the experimental site and the weather conditions experienced during June 1991. This is followed by a description of the equipment and the techniques used to make the measurements. The observed radiation and surface energy budget components are then summarized. 


\subsection{The Experimental Site}

The measurements described in this paper were made at Krebs Ranch, $27 \mathrm{~km}$ west-southwest of Boardman, and $14 \mathrm{~km}$ east-northeast of Arlington, Oregon (Figure 2.1). A photograph of the Krebs ranch site is shown in Figure 2.2. Vegetation at the site was part of a natural grassland-steppe ecosystem and consisted of widely scattered low $(1-4 \mathrm{~cm})$ and high $(18-23 \mathrm{~cm})$ grasses. The steppe is used for the wintertime grazing of livestock, and no livestock were present during the experiment. The site is located $4 \mathrm{~km}$ south of the Columbia River on a broad plain approximately $120 \mathrm{~m}$ above the river.

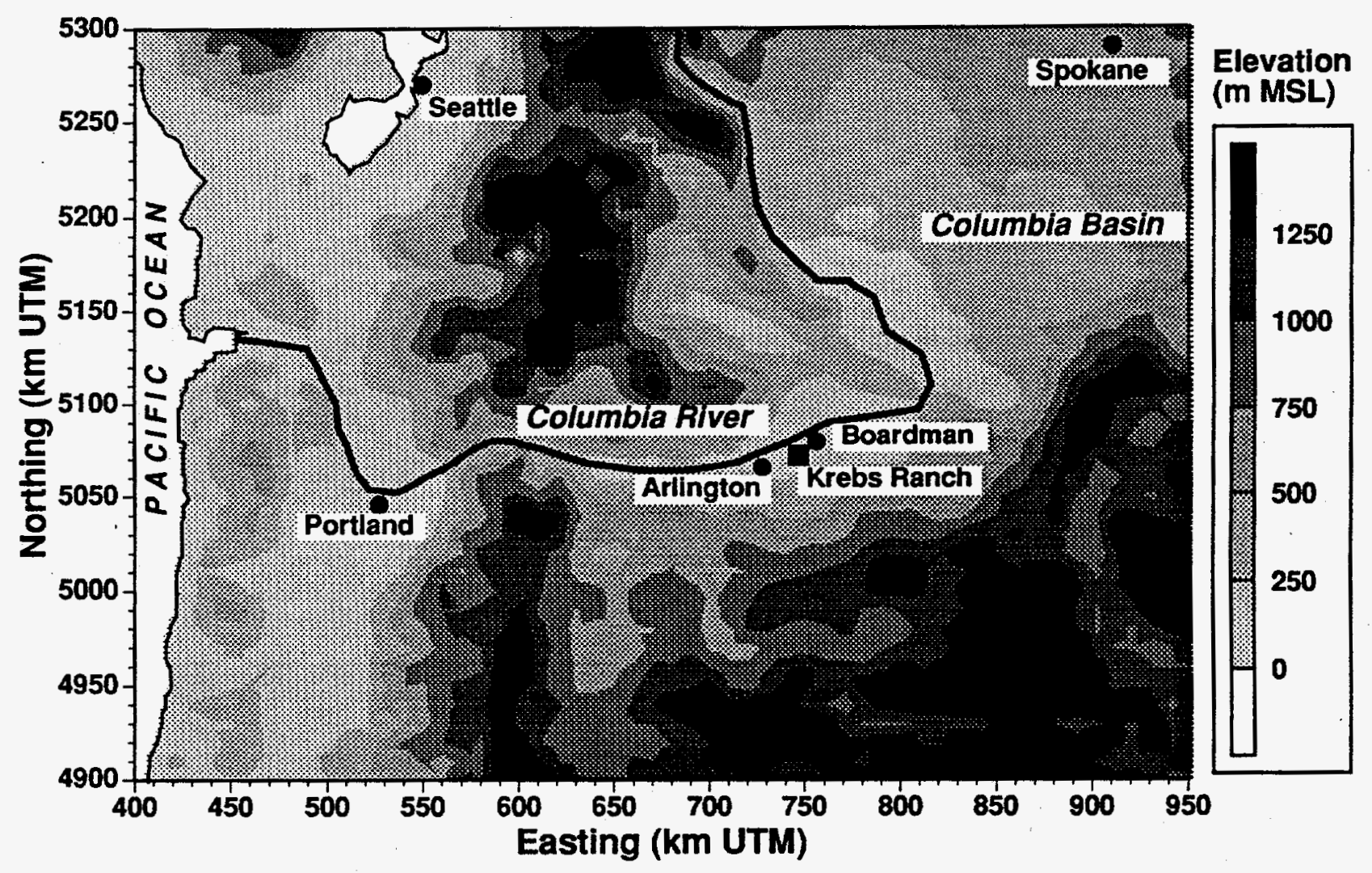

FIGURE 2.1. Map of the Experimental Area 


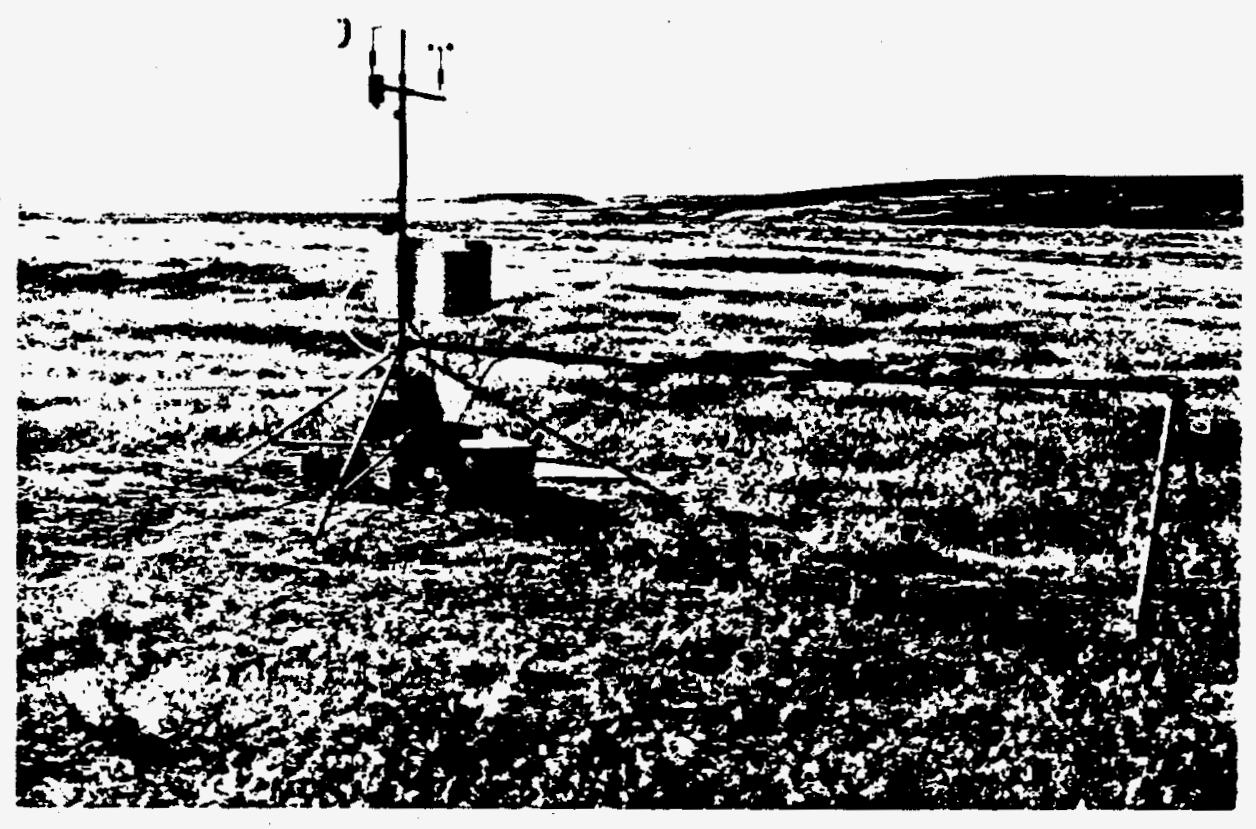

FIGURE 2.2. The Krebs Ranch Site, Looking Toward the Southeast 


\subsection{Weather During the Experiment}

Meteorological data for the 26-d period are presented in Figure 3.1. Surface winds were often strong at the site, typically carrying marine air from the west-southwest through the gorge at speeds of 2 to $10 \mathrm{~m} \mathrm{~s}^{-1}$. These persistent and strong winds are a typical summertime feature caused by

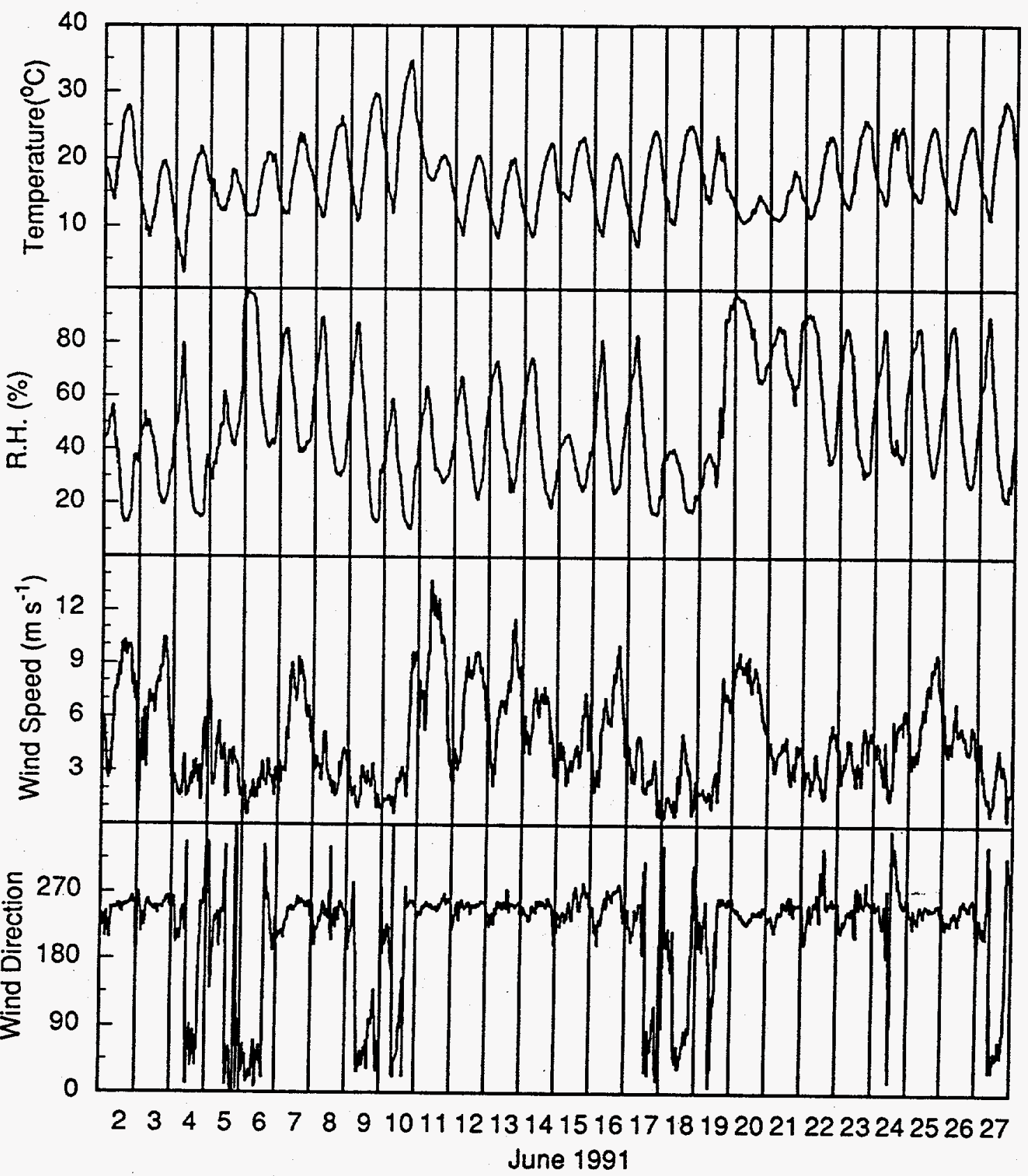

FIGURE 3.1. Basic Meteorological Data at Krebs Ranch, Oregon, from June 2 through 27 
synoptic-scale pressure gradients and channeling. On 10 days during the experimental period, however, the up-valley winds (from west-southwest) in the upper gorge reversed for at least part of the day, bringing drier and warmer continental air from the Columbia Plateau. On these days, 24-h average wind speeds were much weaker (3.0 versus $6.1 \mathrm{~m} \mathrm{~s}^{-1}$ ).

The diurnal temperature range (Figure 3.1) generally was about $10^{\circ} \mathrm{C}$ in the clear marine air when winds blew up the gorge, but approached $20^{\circ} \mathrm{C}$ when clear continental air was advected into the upper gorge from the east (e.g., on June 9 and 10).

The steppe was dry during most of the measurement campaign (Figure 3.1), except for two rainy periods on June 6 and from June 19 to 20 . The data indicate that rain also fell at the site on June 11, although rain was not reported at surrounding stations. Over the course of the month, the predominant signal in the humidity trace was the diurnal variation of humidity from about $30 \%$ in the late afternoon to about $80 \%$ just before sunrise.

June precipitation was more than twice the long-term climatic normal for the month at stations surrounding Krebs Ranch. Cloudiness was also above normal (Doran et al. 1992). Mean June temperatures, however, were near normal. 


\subsection{Measurements and Methods}

The goal of the experiment was to measure the individual radiative and surface energy budget components. The radiative flux measurements were made with commercial radiometers, and the surface energy budget components were made with a Campbell Scientific, Inc. Bowen ratio station (CSI 1988). This station uses the Bowen ratio energy balance technique to determine latent and sensible heat fluxes from measurements of net radiation, soil heat flux, and the vertical gradients of temperature and humidity. Supplemental meteorological variables (wind direction, wind speed, air temperature and air humidity) were also measured. Details regarding equipment exposure, characteristics, and manufacturer are supplied in Table 4.1. Data were sampled at 10-s intervals to obtain 30-min averages, which were recorded on a CSI Model CR7 data logger. All times in this paper are Pacific Standard Time (PST). Half-hour averages and totals are reported at the ending time of the half-hour period.

TABLE 4.1. Instruments Used in the Experiments

\begin{tabular}{|c|c|c|c|}
\hline Instrument/measurements & Manufacturer & Height(m) & Notes \\
\hline $\begin{array}{l}\text { Air temperature and } \\
\text { relative humidity }\end{array}$ & Rotronics & 2.49 & $\begin{array}{l}\text { Installed in 6-plate self- } \\
\text { aspirated radiation shield }\end{array}$ \\
\hline $\begin{array}{l}\text { Net pyrradiometer (net all- } \\
\text { wave irradiance). }\end{array}$ & Swissteco & 1.02 & $\begin{array}{l}\text { Inflated with dry nitrogen } \\
\text { gas }\end{array}$ \\
\hline $\begin{array}{l}\text { Pyranometers (shortwave } \\
\text { irradiance) }\end{array}$ & Eppley Model PSP & $0.89,1.04$ & \\
\hline $\begin{array}{l}\text { Pyrgeometers (longwave } \\
\text { irradiance) }\end{array}$ & Eppley Model PIR & $0.91,1.07$ & \\
\hline $\begin{array}{l}\text { Bowen ratio thermocouples } \\
\text { (air temperature gradient) }\end{array}$ & $\begin{array}{l}\text { Campbell Scientific, } \\
\text { Inc. }\end{array}$ & $0.52,1.51$ & $76 \mathrm{~mm}$ diameter \\
\hline $\begin{array}{l}\text { Cooled mirror hygrometer } \\
\text { (air moisture gradient) }\end{array}$ & $\begin{array}{l}\text { Campbell Scientific, } \\
\text { Inc. }\end{array}$ & $0.52,1.51$ & $\begin{array}{l}\text { Inlets filtered, 2-L mixing } \\
\text { chamber }\end{array}$ \\
\hline $\begin{array}{l}\text { Wind vane and 3-cup } \\
\text { anemometer }\end{array}$ & $\begin{array}{l}\text { Climet Models 012-15 } \\
\text { and 011-3 }\end{array}$ & 2.69 & \\
\hline $\begin{array}{l}\text { Soil heat flux transducers } \\
\text { (2) }\end{array}$ & $\begin{array}{l}\text { Radiation Energy } \\
\text { Balance Systems } \\
\text { (REBS) Model HFT-2 }\end{array}$ & -0.08 & \\
\hline Soil temperature rods (4) & REBS & $\begin{array}{l}-0.02 \\
-0.06\end{array}$ & \\
\hline
\end{tabular}




\subsection{Radiation Budget}

Net all-wave irradiance is defined as

$$
\mathrm{Q} *=\mathrm{K} \downarrow-\mathrm{K} \uparrow+\mathrm{L} \downarrow-\mathrm{L} \uparrow \cdot\left[\mathrm{W} \mathrm{m}^{-2}\right]
$$

where $\mathrm{K} \downarrow$ is the incoming shortwave radiation, $\mathrm{K} \uparrow$ is the reflected solar radiation, $\mathrm{L} \downarrow$ is the incoming longwave radiation, $L \uparrow$ is the outgoing longwave radiation, and a negative $Q^{*}$ indicates net radiative flux away from the surface. Direct measurements of net all-wave irradiance, $Q^{*}$, were made using a net pyrradiometer. The individual components of net all-wave irradiance were also measured, using upward- and downward-looking pyranometers and pyrgeometers. After corrections were made to the measured values (discussed below), estimated measurement accuracies were as follows: net pyrradiometer $\pm 5-10 \%$, pyranometer $\pm 2 \%$, and pyrgeometer $\pm 5-10 \%$.

We applied two corrections to the radiation data. First, on clear days in June, when the sun rises north of east and sets north of west, shadows from the structure holding the radiometers (oriented east-west to the north of the radiometers) were cast on or below the radiometers. Linear interpolations were used to correct the radiometric data for the one to three 30 -min periods when this condition was apparent in the morning and afternoon. Second, following Albrecht and Cox (1977), we corrected measurements of $\mathrm{L} \uparrow$ made in the 4 to $50 \mathrm{~mm}$ spectral range to account for temperature differences that developed between the dome and the case of the pyrgeometer. Corrections to the measured radiation were computed from the equation $\Delta \mathrm{L}=\mathrm{k} \sigma\left(\mathrm{T}_{\mathrm{d}}{ }^{4}-\mathrm{T}_{\mathrm{s}}{ }^{4}\right.$ ), where $\mathrm{k}$ is 4.08 (Albrecht and Cox 1977), $\sigma$ is the Stefan - Boltzmann constant, $T_{d}$ is the dome temperature, and $T_{s}$ is the case temperature. From this equation, a $1{ }^{\circ} \mathrm{C}$ temperature difference between the dome and case will result in a longwave flux correction of 30 to $40 \mathrm{~W} \mathrm{~m}^{-2}$. The dome thermistor was not working properly on the upward-looking pyrgeometer, so that $L \downarrow$ had to be calculated as a residual from Equation (4.1), using the direct measurement of $\mathrm{Q}^{*}$. The resulting back-calculated differences between the dome and case temperatures on clear days (e.g., June 9-12) were reasonable $\left(-0.5\right.$ to $3^{\circ} \mathrm{C}$ ) and gave us confidence in the incoming longwave radiative flux values.

\subsection{Surface Energy Budget}

The energy budget of a soil-atmosphere interface is given by the equation

$$
\mathrm{Q} *=\mathrm{Q}_{\mathrm{G}}+\mathrm{Q}_{\mathrm{H}}+\mathrm{Q}_{\mathrm{E}} \quad\left[\mathrm{W} \mathrm{m}^{-2}\right]
$$

where $Q^{*}$ is net radiation, $Q_{G}$ is ground heat flux, $Q_{H}$ is sensible heat flux, $Q_{E}$ is latent heat flux, and all non-radiative fluxes directed away from the surface are considered positive. Following this energy budget equation, the sum of the latent and sensible heat fluxes is given by the quantity $\left(Q^{*}-Q_{G}\right)$. Accurate measurements of $Q^{*}$ and $Q_{G}$ can thus be used to determine the sum of the "convective fluxes," $Q_{H}$ and $Q_{E}$. The individual convective fluxes can be determined from this sum and from 
measurements of vertical humidity and temperature gradients following the Bowen ratio technique (Bowen 1926; Oke 1978; Fritschen and Simpson 1989) using the equation

$$
\beta=\frac{Q_{H}}{Q_{E}}=\frac{p c_{p} \alpha}{L \epsilon} \frac{\left(\frac{\Delta T}{\Delta z}-\Gamma\right)}{\frac{\Delta e}{\Delta z}}
$$

where $\beta$ is the Bowen ratio, $p$ is atmospheric pressure $(99.0 \mathrm{kPa}), \mathrm{c}_{\mathrm{p}}$ is specific heat of air at constant pressure (1010 $\mathrm{J} \mathrm{kg}^{-1} \mathrm{~K}^{-1}$ ), $\alpha$ is the ratio of the eddy diffusivities for heat $\mathrm{K}_{\mathrm{H}}$ and water vapor $\mathrm{K}_{\mathrm{w}}, \mathrm{T}$ is temperature in ${ }^{\circ} \mathrm{C}, \mathrm{z}$ is height in $\mathrm{m}, \Gamma$ is the dry adiabatic lapse rate $\left(0.0098 \mathrm{~K} \mathrm{~m}^{-1}\right)$, $\mathrm{L}$ is the latent heat of vaporization of water $\left(2.47 \mathrm{MJ} \mathrm{kg}^{-1}\right), \epsilon$ is the ratio of the molecular weights of water and dry air (0.622), and $\mathrm{e}$ is water vapor pressure in $\mathrm{kPa}$. Once $\beta$ has been determined from the temperature and humidity gradients over the height interval $\Delta z(1.51-0.52=0.99 \mathrm{~m}$ in the present instance), then the individual convective fluxes are given by

$$
Q_{E}=\frac{1}{1+\beta}\left(Q^{*}-Q_{G}\right) \quad\left[W m^{-2}\right]
$$

and

$$
Q_{H}=\beta Q_{E} \quad\left[W m^{-2}\right]
$$

Determination of the individual convective fluxes thus requires measurements of net radiation, pressure, soil heat flux, the vertical gradients of temperature and water vapor pressure, and temperature (because $\mathrm{L}$ is a weak function of temperature). The net radiation measurements were discussed previously. The dependence on atmospheric pressure is weak, so the mean pressure at the Krebs Ranch site is used in the computations. The soil heat flux calculations, the determination of the gradients in Equation (4.3), and the treatment of the special case in which $\beta$ approaches -1 in Equation (4.4) are discussed next.

The soil heat flux at the surface $Q_{G}$ was determined from the equation

$$
\mathrm{Q}_{\mathrm{G}}=\mathrm{Q}_{\mathrm{F}}+\mathrm{Q}_{\mathrm{S}} \quad\left[\mathrm{W} \mathrm{\textrm {m } ^ { - 2 }}\right]
$$

where $Q_{F}$ is the average of the fluxes measured with two soil heat flux plates buried at depths of $0.08 \mathrm{~m}$, and $\mathrm{Q}_{\mathrm{s}}$ is a correction for the change of heat storage in the soil column above the flux plates. Then 


$$
\mathrm{Q}_{s}=\mathrm{C}_{s} \frac{\Delta \mathrm{T}_{\mathrm{s}}}{\Delta \mathrm{t}} \mathrm{dz} \quad\left[\mathrm{W} \mathrm{m}^{-2}\right]
$$

where $C_{s}$ is the soil volumetric heat capacity, and $T_{s}$ is the average temperature of the soil above the plates as measured using 4 parallel thermocouples ( 2 sets of 2 ) that were inserted horizontally into the soil at depths of 0.02 and $0.06 \mathrm{~m}$ at locations near each of the buried soil heat flux plates. $\mathrm{C}_{8}$ varies somewhat with soil moisture and was calculated using the deVries (1975) method described in Appendix A.

The vertical gradients of temperature and humidity required in Equation (4.3) were measured using the CSI Bowen ratio station, in which temperatures were measured at two heights $(0.52$ and $1.51 \mathrm{~m}$ ) using freely-exposed, nonaspirated, $76 \mathrm{~mm}$-dia chromel-constantan thermocouples. Air humidity was measured at the same two heights by a cooled mirror dew point hygrometer. Continuous air samples pumped from the two heights were alternately shunted to the cooled mirror after passing through 2-L mixing volumes at a rate of $0.4 \mathrm{~L}$ per min, giving a 5-min time constant. Valves were switched by a data acquisition system every $2 \mathrm{~min}$ to allow alternate sampling of the humidity at the two heights. Readings were taken over a $1 \mathrm{~min} 20$-s period following a 40 -s period in which the dew point temperature was allowed to stabilize. The air temperature and dew point temperature were measured every second, and vapor pressure was calculated in the data acquisition system using an equation described by Lowe (1976). The average temperatures and vapor pressures were calculated at each height over a 30-min period, and the gradients required in Equation (4.3) were determined from these 30-min average values. Net radiation and soil heat flux values were calculated over the same 30-min interval from 10-s samples, and latent and sensible heat fluxes were calculated from Equations (4.4) and (4.5) under the assumption that $\alpha=1$ or, equivalently, that turbulence is equally effective in transporting sensible heat and water vapor. This assumption is somewhat controversial, but is accepted here in accordance with others using the Bowen ratio method in the absence of definitive evidence for an alternative value.

From Equation (4.4), $\mathrm{Q}_{\mathrm{E}}$ can become unrealistically large when $\beta$ approaches -1 (i.e., when the sensible and latent heat fluxes become equal in magnitude but opposite in sign). This transient condition generally occurs in the early morning and late afternoon when the sum of the convective fluxes is small. During this condition, for $-0.7 \leq \beta \leq-1.3$ the flux calculations from Equation (4.4) and Equation (4.5) were rejected, and the latent and sensible heat fluxes were determined by a time interpolation under the constraint that Equation (4.2), the surface energy budget equation, was always satisfied. Using this criterion, $4 \%$ of the 30 -min average convective fluxes were replaced during the 26-d period. 


\subsection{Analysis of Data}

The data analysis focuses on the time series of 30-min-average radiation and surface energy budget terms (Figure 5.1) and the daily totals of these terms (Table 5.1). The daily and daytime totals are listed; nighttime totals can be calculated by taking their difference. The daytime total consists of the sum of 3130 -min-average values, i.e., a $151 / 2$-h day beginning at 0430 and ending at 2000 PST. For comparison, the times of astronomical sunrise and sunset during the 26-d period varied from 0414 to 0420 and from 1936 to 1949 PST. The following discussion uses data from Figure 5.1 and Table 5.1.

\subsection{Radiation Budget Terms}

The extraterrestrial solar irradiance $\left(\mathrm{K}_{\mathrm{x}}\right)$, the measured net all-wave irradiance, and the individually measured components of net all-wave irradiance are shown in the upper panels of Figure 5.1a and 5.1b for the 26-d experimental period. Data for the last two days are missing because four radiometers were removed to support a separate experiment.

\subsubsection{Extraterrestrial Solar Irradiance}

Extraterrestrial solar irradiance is the theoretical flux at the earth's surface in the absence of the earth's atmosphere and was computed by a solar model (Whiteman and Allwine 1986) using a value of $1353 \pm 20 \mathrm{~W} \mathrm{~m}^{-2}$ (Oke 1978) for the solar constant.

\subsubsection{Incoming Solar Radiation}

Over the 26-d period, incoming solar radiation at the surface was $59 \%$ of the extraterrestrial radiation, so that $41 \%$ of the extraterrestrial radiation was absorbed, reflected, or scattered back to space by water vapor, aerosols, clouds, and atmospheric gases. On cloudy days (e.g., June 19), only $18 \%$ of the extraterrestrial radiation reached the ground, while on cloudless days (e.g., June 12) more than $75 \%$ of the extraterrestrial radiation reached the ground.

Incoming solar radiation consists of two components-direct and diffuse radiation. Unfortunately, equipment was unavailable to measure these components separately. On clear days at sea level, typically about $15-20 \%$ of the daily total incoming solar radiation is in the diffuse component (Miller 1981). On cloudy days, the diffuse component typically increases at the expense of the direct component but, because of enhanced reflection to space at the cloud tops, the total incoming radiation at the ground is generally reduced relative to clear days. It is well-known, however, that instantaneous values of total incoming radiation can be enhanced at a site under partly cloudy conditions if reflections from the side of a nearby cloud add to the direct radiation received while the site is in the sunlight. The highest daily value of 30-min-average incoming solar radiation $\left(1006 \mathrm{~W} \mathrm{~m}^{-2}\right)$ was at 


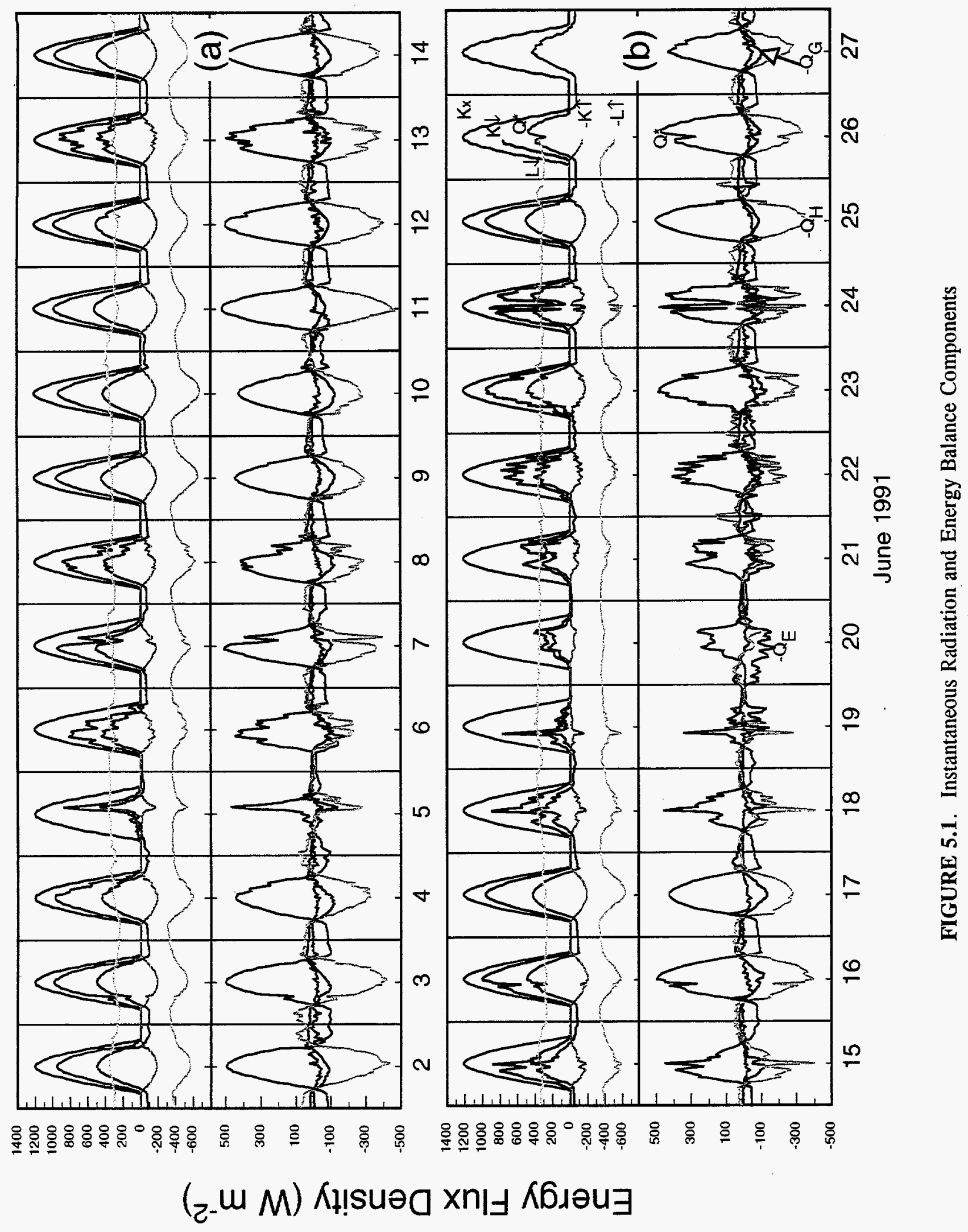


TABLE 5.1. Daily and Daytime Totals $\left(\mathrm{MJ} \mathrm{m}^{-2} \mathrm{~d}^{-1}\right)$ of Radiative and Surface Energy Budget Components at Krebs Ranch, Oregon, as Calculated from 30-min Averages

\begin{tabular}{|c|c|c|c|c|c|c|c|c|c|c|}
\hline June & & $\mathrm{K}_{\mathrm{x}}$ & $\mathrm{K} \downarrow$ & $\mathrm{K} \uparrow$ & $L \downarrow$ & $\mathrm{L} \uparrow$ & $\mathrm{Q}^{*}$ & $\mathrm{Q}_{\mathrm{G}}$ & $Q_{E}$ & $\mathrm{Q}_{\mathrm{H}}$ \\
\hline 2 & $\begin{array}{l}\text { daily } \\
\text { day }\end{array}$ & $\begin{array}{l}40.73 \\
40.73\end{array}$ & $\begin{array}{l}29.30 \\
29.30\end{array}$ & $\begin{array}{l}5.96 \\
5.96\end{array}$ & $\begin{array}{l}26.80 \\
16.89\end{array}$ & $\begin{array}{l}38.78 \\
26.28\end{array}$ & $\begin{array}{l}11.35 \\
13.94\end{array}$ & $\begin{array}{l}1.16 \\
1.97\end{array}$ & $\begin{array}{l}0.83 \\
0.51\end{array}$ & $\begin{array}{r}9.37 \\
11.47\end{array}$ \\
\hline 3 & $\begin{array}{l}\text { daily } \\
\text { day }\end{array}$ & $\begin{array}{l}40.81 \\
40.81\end{array}$ & $\begin{array}{l}30.11 \\
30.11\end{array}$ & $\begin{array}{l}6.30 \\
6.30\end{array}$ & $\begin{array}{l}23.06 \\
14.45\end{array}$ & $\begin{array}{l}35.56 \\
24.13\end{array}$ & $\begin{array}{l}11.30 \\
14.13\end{array}$ & $\begin{array}{l}0.79 \\
1.79\end{array}$ & $\begin{array}{l}0.49 \\
0.38\end{array}$ & $\begin{array}{l}10.02 \\
11.96\end{array}$ \\
\hline 4 & $\begin{array}{l}\text { daily } \\
\text { day }\end{array}$ & $\begin{array}{l}40.88 \\
40.88\end{array}$ & $\begin{array}{l}29.12 \\
29.12\end{array}$ & $\begin{array}{l}6.07 \\
6.07\end{array}$ & $\begin{array}{l}24.38 \\
15.11\end{array}$ & $\begin{array}{l}37.41 \\
25.90\end{array}$ & $\begin{array}{l}10.02 \\
12.27\end{array}$ & $\begin{array}{l}1.68 \\
2.59\end{array}$ & $\begin{array}{l}0.45 \\
0.50\end{array}$ & $\begin{array}{l}7.89 \\
9.19\end{array}$ \\
\hline 5 & $\begin{array}{l}\text { daily } \\
\text { day }\end{array}$ & $\begin{array}{l}40.95 \\
40.95\end{array}$ & $\begin{array}{l}8.51 \\
8.51\end{array}$ & $\begin{array}{l}1.62 \\
1.62\end{array}$ & $\begin{array}{l}29.05 \\
18.47\end{array}$ & $\begin{array}{l}33.93 \\
21.73\end{array}$ & $\begin{array}{l}2.01 \\
3.62\end{array}$ & $\begin{array}{l}0.27 \\
0.72\end{array}$ & $\begin{array}{l}0.13 \\
0.21\end{array}$ & $\begin{array}{l}1.60 \\
2.69\end{array}$ \\
\hline 6 & $\begin{array}{l}\text { daily } \\
\text { day }\end{array}$ & $\begin{array}{l}41.02 \\
41.02\end{array}$ & $\begin{array}{l}21.85 \\
21.85\end{array}$ & $\begin{array}{l}4.26 \\
4.26\end{array}$ & $\begin{array}{l}28.75 \\
18.67\end{array}$ & $\begin{array}{l}36.77 \\
25.47\end{array}$ & $\begin{array}{r}9.58 \\
10.80\end{array}$ & $\begin{array}{l}1.17 \\
1.71\end{array}$ & $\begin{array}{l}3.30 \\
3.56\end{array}$ & $\begin{array}{l}5.11 \\
5.53\end{array}$ \\
\hline 7 & $\begin{array}{l}\text { daily } \\
\text { day }\end{array}$ & $\begin{array}{l}41.08 \\
41.08\end{array}$ & $\begin{array}{l}23.95 \\
23.95\end{array}$ & $\begin{array}{l}4.79 \\
4.79\end{array}$ & $\begin{array}{l}28.30 \\
18.75\end{array}$ & $\begin{array}{l}37.25 \\
25.87\end{array}$ & $\begin{array}{l}10.20 \\
12.04\end{array}$ & $\begin{array}{l}1.33 \\
1.88\end{array}$ & $\begin{array}{l}0.93 \\
1.17\end{array}$ & $\begin{array}{l}7.94 \\
8.99\end{array}$ \\
\hline 8 & $\begin{array}{l}\text { daily } \\
\text { day }\end{array}$ & $\begin{array}{l}41.14 \\
41.14\end{array}$ & $\begin{array}{l}25.79 \\
25.79\end{array}$ & $\begin{array}{l}5.28 \\
5.28\end{array}$ & $\begin{array}{l}27.58 \\
18.32\end{array}$ & $\begin{array}{l}39.45 \\
27.94\end{array}$ & $\begin{array}{r}8.65 \\
10.90\end{array}$ & $\begin{array}{l}1.86 \\
2.65\end{array}$ & $\begin{array}{l}0.68 \\
0.89\end{array}$ & $\begin{array}{l}6.11 \\
7.36\end{array}$ \\
\hline 9* & $\begin{array}{l}\text { daily } \\
\text { day }\end{array}$ & $\begin{array}{l}41.19 \\
41.19\end{array}$ & $\begin{array}{l}29.64 \\
29.64\end{array}$ & $\begin{array}{l}5.98 \\
5.98\end{array}$ & $\begin{array}{l}28.11 \\
18.37\end{array}$ & $\begin{array}{l}41.26 \\
29.58\end{array}$ & $\begin{array}{l}10.50 \\
12.45\end{array}$ & $\begin{array}{l}2.09 \\
3.00\end{array}$ & $\begin{array}{l}0.96 \\
1.11\end{array}$ & $\begin{array}{l}7.46 \\
8.34\end{array}$ \\
\hline $10^{*}$ & $\begin{array}{l}\text { daily } \\
\text { day }\end{array}$ & $\begin{array}{l}41.24 \\
41.24\end{array}$ & $\begin{array}{l}29.26 \\
29.26\end{array}$ & $\begin{array}{l}5.90 \\
5.90\end{array}$ & $\begin{array}{l}30.46 \\
19.76\end{array}$ & $\begin{array}{l}43.32 \\
30.98\end{array}$ & $\begin{array}{l}10.50 \\
12.14\end{array}$ & $\begin{array}{l}2.45 \\
3.24\end{array}$ & $\begin{array}{l}0.07 \\
0.37\end{array}$ & $\begin{array}{l}7.99 \\
8.53\end{array}$ \\
\hline $11^{*}$ & $\begin{array}{l}\text { daily } \\
\text { day }\end{array}$ & $\begin{array}{l}41.28 \\
41.28\end{array}$ & $\begin{array}{l}30.66 \\
30.66\end{array}$ & $\begin{array}{l}6.36 \\
6.36\end{array}$ & $\begin{array}{l}26.15 \\
16.20\end{array}$ & $\begin{array}{l}37.68 \\
25.66\end{array}$ & $\begin{array}{l}12.76 \\
14.84\end{array}$ & $\begin{array}{l}0.69 \\
1.36\end{array}$ & $\begin{array}{l}1.51 \\
1.58\end{array}$ & $\begin{array}{l}10.56 \\
11.90\end{array}$ \\
\hline 12 & $\begin{array}{l}\text { daily } \\
\text { day }\end{array}$ & $\begin{array}{r}41.32 \\
41 \cdot .32\end{array}$ & $\begin{array}{l}31.29 \\
31.29\end{array}$ & $\begin{array}{l}6.53 \\
6.53\end{array}$ & $\begin{array}{l}23.81 \\
15.49\end{array}$ & $\begin{array}{l}36.59 \\
25.70\end{array}$ & $\begin{array}{l}11.98 \\
14.55\end{array}$ & $\begin{array}{l}1.09 \\
1.96\end{array}$ & $\begin{array}{l}0.53 \\
0.78\end{array}$ & $\begin{array}{l}10.36 \\
11.80\end{array}$ \\
\hline 13 & $\begin{array}{l}\text { daily } \\
\text { day }\end{array}$ & $\begin{array}{l}41.36 \\
41.36\end{array}$ & $\begin{array}{l}28.54 \\
28.54\end{array}$ & $\begin{array}{l}6.03 \\
6.03\end{array}$ & $\begin{array}{l}24.63 \\
16.27\end{array}$ & $\begin{array}{l}36.11 \\
25.31\end{array}$ & $\begin{array}{l}11.03 \\
13.46\end{array}$ & $\begin{array}{l}1.06 \\
1.89\end{array}$ & $\begin{array}{l}0.57 \\
0.52\end{array}$ & $\begin{array}{r}9.40 \\
11.04\end{array}$ \\
\hline $14^{*}$ & $\begin{array}{l}\text { daily } \\
\text { day }\end{array}$ & $\begin{array}{l}41.39 \\
41.39\end{array}$ & $\begin{array}{l}31.35 \\
31.35\end{array}$ & $\begin{array}{l}6.60 \\
6.60\end{array}$ & $\begin{array}{l}24.52 \\
15.76\end{array}$ & $\begin{array}{l}37.34 \\
26.29\end{array}$ & $\begin{array}{l}11.93 \\
14.23\end{array}$ & $\begin{array}{l}1.46 \\
2.32\end{array}$ & $\begin{array}{l}0.41 \\
0.55\end{array}$ & $\begin{array}{l}10.06 \\
11.36\end{array}$ \\
\hline 15 & $\begin{array}{l}\text { total } \\
\text { day }\end{array}$ & $\begin{array}{l}41.42 \\
41.42\end{array}$ & $\begin{array}{l}19.42 \\
19.42\end{array}$ & $\begin{array}{l}4.07 \\
4.07\end{array}$ & $\begin{array}{l}29.05 \\
18.98\end{array}$ & $\begin{array}{l}37.94 \\
26.29\end{array}$ & $\begin{array}{l}6.45 \\
8.04\end{array}$ & $\begin{array}{l}1.35 \\
1.80\end{array}$ & $\begin{array}{l}0.29 \\
0.31\end{array}$ & $\begin{array}{l}4.82 \\
5.93\end{array}$ \\
\hline
\end{tabular}

*clear days 
TABLE 5.1. (contd)

\begin{tabular}{|c|c|c|c|c|c|c|c|c|c|c|}
\hline June & & $\mathrm{K}_{\mathrm{x}}$ & $\mathrm{K} \downarrow$ & $\mathrm{K} \uparrow$ & $\mathrm{L} \downarrow$ & $\mathrm{L} \uparrow$ & $\mathrm{Q}^{*}$ & $\mathrm{Q}_{\mathrm{G}}$ & $\mathrm{Q}_{\mathrm{E}}$ & $\mathrm{Q}_{\mathrm{H}}$ \\
\hline 16 & $\begin{array}{l}\text { total } \\
\text { day }\end{array}$ & $\begin{array}{l}41.44 \\
41.44\end{array}$ & $\begin{array}{l}30.51 \\
30.51\end{array}$ & $\begin{array}{l}6.51 \\
6.51\end{array}$ & $\begin{array}{l}24.26 \\
15.93\end{array}$ & $\begin{array}{l}36.76 \\
25.98\end{array}$ & $\begin{array}{l}11.49 \\
13.95\end{array}$ & $\begin{array}{l}1.14 \\
2.13\end{array}$ & $\begin{array}{l}0.28 \\
0.49\end{array}$ & $\begin{array}{l}10.07 \\
11.33\end{array}$ \\
\hline $17^{*}$ & $\begin{array}{l}\text { total } \\
\text { day }\end{array}$ & $\begin{array}{l}41.46 \\
41.46\end{array}$ & $\begin{array}{l}30.75 \\
30.75\end{array}$ & $\begin{array}{l}6.51 \\
6.51\end{array}$ & $\begin{array}{l}25.03 \\
16.46\end{array}$ & $\begin{array}{l}38.98 \\
28.17\end{array}$ & $\begin{array}{l}10.29 \\
12.53\end{array}$ & $\begin{array}{l}1.83 \\
2.91\end{array}$ & $\begin{array}{l}0.27 \\
0.48\end{array}$ & $\begin{array}{l}8.19 \\
9.14\end{array}$ \\
\hline 18 & $\begin{array}{l}\text { total } \\
\text { day }\end{array}$ & $\begin{array}{l}41.48 \\
41.48\end{array}$ & $\begin{array}{l}17.57 \\
17.57\end{array}$ & $\begin{array}{l}3.64 \\
3.64\end{array}$ & $\begin{array}{l}29.88 \\
19.61\end{array}$ & $\begin{array}{l}37.96 \\
26.32\end{array}$ & $\begin{array}{l}5.86 \\
7.23\end{array}$ & $\begin{array}{l}1.36 \\
2.02\end{array}$ & $\begin{array}{l}0.06 \\
0.19\end{array}$ & $\begin{array}{l}4.44 \\
5.01\end{array}$ \\
\hline 19 & $\begin{array}{l}\text { total } \\
\text { day }\end{array}$ & $\begin{array}{l}41.49 \\
41.49\end{array}$ & $\begin{array}{l}7.31 \\
7.31\end{array}$ & $\begin{array}{l}1.44 \\
1.44\end{array}$ & $\begin{array}{l}30.92 \\
20.31\end{array}$ & $\begin{array}{l}34.93 \\
23.37\end{array}$ & $\begin{array}{l}1.86 \\
2.81\end{array}$ & $\begin{array}{l}0.18 \\
0.61\end{array}$ & $\begin{array}{l}0.92 \\
0.96\end{array}$ & $\begin{array}{r}0.76 \\
-1.24\end{array}$ \\
\hline 20 & $\begin{array}{l}\text { total } \\
\text { day }\end{array}$ & $\begin{array}{l}41.49 \\
41.49\end{array}$ & $\begin{array}{l}9.47 \\
9.47\end{array}$ & $\begin{array}{l}1.63 \\
1.63\end{array}$ & $\begin{array}{l}30.16 \\
19.43\end{array}$ & $\begin{array}{l}32.42 \\
21.43\end{array}$ & $\begin{array}{l}5.57 \\
6.01\end{array}$ & $\begin{array}{l}-1.04 \\
-0.03\end{array}$ & $\begin{array}{l}6.01 \\
4.94\end{array}$ & $\begin{array}{l}0.60 \\
1.11\end{array}$ \\
\hline 21 & $\begin{array}{l}\text { total } \\
\text { day }\end{array}$ & $\begin{array}{l}41.50 \\
41.50\end{array}$ & $\begin{array}{l}14.86 \\
14.86\end{array}$ & $\begin{array}{l}2.80 \\
2.80\end{array}$ & $\begin{array}{l}28.98 \\
18.79\end{array}$ & $\begin{array}{l}34.01 \\
22.81\end{array}$ & $\begin{array}{l}7.03 \\
8.04\end{array}$ & $\begin{array}{l}1.07 \\
1.62\end{array}$ & $\begin{array}{l}3.02 \\
2.83\end{array}$ & $\begin{array}{l}2.93 \\
3.59\end{array}$ \\
\hline 22 & $\begin{array}{l}\text { total } \\
\text { day }\end{array}$ & $\begin{array}{l}41.49 \\
41.49\end{array}$ & $\begin{array}{l}20.65 \\
20.65\end{array}$ & $\begin{array}{l}4.00 \\
4.00\end{array}$ & $\begin{array}{l}28.66 \\
18.90\end{array}$ & $\begin{array}{l}36.79 \\
25.41\end{array}$ & $\begin{array}{r}8.51 \\
10.14\end{array}$ & $\begin{array}{l}1.55 \\
2.22\end{array}$ & $\begin{array}{l}3.07 \\
2.34\end{array}$ & $\begin{array}{l}3.89 \\
5.59\end{array}$ \\
\hline 23 & $\begin{array}{l}\text { total } \\
\text { day }\end{array}$ & $\begin{array}{l}41.49 \\
41.49\end{array}$ & $\begin{array}{l}28.31 \\
28.31\end{array}$ & $\begin{array}{l}5.56 \\
5.56\end{array}$ & $\begin{array}{l}27.77 \\
18.07\end{array}$ & $\begin{array}{l}39.14 \\
27.47\end{array}$ & $\begin{array}{l}11.38 \\
13.36\end{array}$ & $\begin{array}{l}1.94 \\
2.65\end{array}$ & $\begin{array}{l}2.50 \\
2.25\end{array}$ & $\begin{array}{l}6.93 \\
8.45\end{array}$ \\
\hline 24 & $\begin{array}{l}\text { total } \\
\text { day }\end{array}$ & $\begin{array}{l}41.48 \\
41.48\end{array}$ & $\begin{array}{l}23.79 \\
23.79\end{array}$ & $\begin{array}{l}4.76 \\
4.76\end{array}$ & $\begin{array}{l}27.99 \\
18.52\end{array}$ & $\begin{array}{l}38.42 \\
26.74\end{array}$ & $\begin{array}{r}8.59 \\
10.80\end{array}$ & $\begin{array}{l}1.35 \\
2.11\end{array}$ & $\begin{array}{l}2.04 \\
1.73\end{array}$ & $\begin{array}{l}5.21 \\
6.97\end{array}$ \\
\hline 25 & $\begin{array}{l}\text { total } \\
\text { day }\end{array}$ & $\begin{array}{l}41.46 \\
41.46\end{array}$ & $\begin{array}{l}29.10 \\
29.10\end{array}$ & $\begin{array}{l}5.79 \\
5.79\end{array}$ & $\begin{array}{l}27.40 \\
17.58\end{array}$ & $\begin{array}{l}38.41 \\
26.74\end{array}$ & $\begin{array}{l}12.29 \\
14.14\end{array}$ & $\begin{array}{l}1.40 \\
2.05\end{array}$ & $\begin{array}{l}2.24 \\
1.89\end{array}$ & $\begin{array}{r}8.65 \\
10.20\end{array}$ \\
\hline 26 & $\begin{array}{l}\text { total } \\
\text { day }\end{array}$ & $\begin{array}{l}41.44 \\
41.44\end{array}$ & $\begin{array}{l}\text { miss } \\
\text { miss }\end{array}$ & $\begin{array}{l}\text { miss } \\
\text { miss }\end{array}$ & $\begin{array}{l}\text { miss } \\
\text { miss }\end{array}$ & $\begin{array}{l}\text { miss } \\
\text { miss }\end{array}$ & $\begin{array}{l}10.29 \\
12.65\end{array}$ & $\begin{array}{l}1.53 \\
2.32\end{array}$ & $\begin{array}{l}1.35 \\
1.23\end{array}$ & $\begin{array}{l}7.40 \\
9.10\end{array}$ \\
\hline 27 & $\begin{array}{l}\text { total } \\
\text { day }\end{array}$ & $\begin{array}{l}41.42 \\
41.42\end{array}$ & $\begin{array}{l}\text { miss } \\
\text { miss }\end{array}$ & $\begin{array}{l}\text { miss } \\
\text { miss }\end{array}$ & $\begin{array}{l}\text { miss } \\
\text { miss }\end{array}$ & $\begin{array}{l}\text { miss } \\
\text { miss }\end{array}$ & $\begin{array}{r}8.45 \\
10.63\end{array}$ & $\begin{array}{l}1.66 \\
2.40\end{array}$ & $\begin{array}{l}1.34 \\
1.12\end{array}$ & $\begin{array}{l}5.46 \\
7.11\end{array}$ \\
\hline mean & $\begin{array}{l}\text { total } \\
\text { day }\end{array}$ & $\begin{array}{l}41.29 \\
41.29\end{array}$ & $\begin{array}{l}24.21 \\
24.21\end{array}$ & $\begin{array}{l}4.93 \\
4.93\end{array}$ & $\begin{array}{l}27.32 \\
17.71\end{array}$ & $\begin{array}{l}-37.39 \\
-25.89\end{array}$ & $\begin{array}{r}9.23 \\
11.14\end{array}$ & $\begin{array}{l}1.25 \\
2.00\end{array}$ & $\begin{array}{l}1.32 \\
1.27\end{array}$ & $\begin{array}{l}6.66 \\
7.88\end{array}$ \\
\hline $\begin{array}{l}\text { standard } \\
\text { deviation }\end{array}$ & $\begin{array}{l}\text { total } \\
\text { day }\end{array}$ & $\begin{array}{l}0.23 \\
0.23\end{array}$ & $\begin{array}{l}7.50 \\
7.50\end{array}$ & $\begin{array}{l}1.63 \\
1.63\end{array}$ & $\begin{array}{l}2.26 \\
1.60\end{array}$ & $\begin{array}{l}2.29 \\
2.16\end{array}$ & $\begin{array}{l}2.85 \\
3.26\end{array}$ & $\begin{array}{l}0.68 \\
0.72\end{array}$ & $\begin{array}{l}1.35 \\
1.12\end{array}$ & $\begin{array}{l}2.94 \\
3.21\end{array}$ \\
\hline
\end{tabular}

*clear days 
midday on the partly cloudy day of June 16; the highest value on a clear day was $986 \mathrm{~W} \mathrm{~m}^{-2}$ on June 12; the lowest value ( $399 \mathrm{~W} \mathrm{~m}^{-2}$ ) of incoming solar radiation was received on the cloudy/rainy day of June 20 . The existence of daytime cloudiness is indicated in the time series by decreases in incoming solar radiation relative to the clear day curves and, on nonovercast days, by rapid temporal fluctuations in incoming solar radiation. By arbitrarily defining clear or partly cloudy days as days having daily total incoming radiation greater than $20 \mathrm{MJ} \mathrm{m}^{-2} \mathrm{~d}^{-1}$, we find that the 26-d period consists of 20 clear or partly cloudy days and 6 cloudy days.

\subsubsection{Reflected Solar Radiation}

The fraction of the incoming solar radiation that is reflected at a site depends on the reflectance of bare soil and vegetation and, for nonisotropic reflectors, will be a function of the incident angle of the solar beam. The highest value of reflected radiation $\left(200 \mathrm{~W} \mathrm{~m}^{-2}\right)$ occurred about midday on the partly cloudy day of June 16 , although several clear days had values nearly as high. The daily average albedo was 0.20 , which varied from 0.17 to 0.21 on individual days.

\subsubsection{Incoming and Outgoing Longwave Radiation}

The incoming longwave radiation is the largest supplier of energy to the ecosystem over a 24-h period. Unlike the solar radiative fluxes that occur only during daytime, the incoming longwave irradiance is reasonably steady both night and day and provides a moderating influence. The outgoing longwave irradiance also occurs night and day and is the largest of all the daily averaged radiative fluxes. During daytime, this upward flux counters the large gains from incoming solar radiation and dissipates the excess heat that would otherwise occur in the ecosystem. However, the longwave losses continue into the night (but at a reduced rate that depends on ecosystem temperature). During the experimental period, the daily total outgoing longwave radiation was always much greater than the incoming longwave radiation, which means that the net longwave radiation $(L \downarrow-L \uparrow)$ represents a net energy loss from this ecosystem of about $10 \mathrm{MJ} \mathrm{d}^{-1}$.

For incoming longwave radiation, 30-min-average values ranged from $237 \mathrm{~W} \mathrm{~m}^{-2}$ at sunrise on the clear day of June 4 to $407 \mathrm{~W} \mathrm{~m}^{-2}$ during an evening thunderstorm on June 10 . For outgoing longwave radiation, 30-min-average values ranged from 308 at sunrise on June 4 to $682 \mathrm{~W} \mathrm{~m}^{-2}$ in the early afternoon on the clear day of June 10 .

Over a 24-d period at Krebs Ranch, the incoming longwave radiation maintained a daily mean value of 316 , a daytime mean value of 317 , and a nighttime mean value of $314 \mathrm{~W} \mathrm{~m}^{-2}$. For comparison, outgoing longwave radiation maintained a daily mean value of 433 , a daytime mean value of 464 , and a nighttime mean value of $376 \mathrm{~W} \mathrm{~m}^{-2}$.

The Stefan-Boltzmann equation, $\mathrm{L}=\epsilon \sigma \mathrm{T}^{4}$, where $\epsilon$ is emissivity and $\sigma$ is the StefanBoltzmann constant $\left(5.67 \times 10^{-8} \mathrm{~W} \mathrm{~m}^{-2} \mathrm{~K}^{-4}\right)$, relates longwave irradiances to radiating temperatures. By assuming an emissivity of 1 , the effective radiating temperatures of the sky and ecosystem can be determined by substituting the absolute values of $L \downarrow$ and $L \uparrow$ into the formula for $L$. The minimum effective radiating temperature of the sky (ecosystem) for the 24 -d period was $-18.8^{\circ} \mathrm{C}\left(3.3^{\circ} \mathrm{C}\right)$, and the maximum was $18.0^{\circ} \mathrm{C}\left(58.0^{\circ} \mathrm{C}\right)$. The mean effective radiating temperature of the sky (ecosystem) was $0.1^{\circ} \mathrm{C}\left(22.4^{\circ} \mathrm{C}\right)$, with daytime mean values of $0.4^{\circ} \mathrm{C}\left(27.6^{\circ} \mathrm{C}\right)$ and nighttime values of $-0.3^{\circ} \mathrm{C}$ $\left(12.2^{\circ} \mathrm{C}\right)$. 


\subsubsection{Net All-Wave Radiation}

Net all-wave radiation is equivalent to net longwave radiation at night when the solar irradiances are zero. During the night, the outgoing longwave radiation is partly counterbalanced by the incoming longwave radiation, leaving a net radiative loss from the ecosystem. The net radiative loss is usually a maximum just after sunset when the rate of longwave loss from the heated ground is still great, but the rate of loss decreases with time through the night. During daytime, however, the net longwave loss, which continues into the day, is counterbalanced by a large net shortwave gain, because the incoming shortwave radiation is much larger than the reflected radiation and can attain values in midday that are larger than either of the longwave fluxes.

In the 26-d time series of net all-wave radiation (Figure 5.1), net radiation changes sign twice per day. The morning sign change marks the end of the nighttime period, when the steppe ecosystem draws heat from the soil and air to meet the net radiation deficit. Absorption of solar radiation in the morning usually becomes equal to the net longwave loss about an hour after sunrise when the sun is around $10^{\circ}$ above the horizon. The second sign change occurs in late afternoon about an hour before sunset, when the diminishing quantity of absorbed solar radiation reaches the level of the net longwave loss, a loss that is greater in the afternoon than in the morning.

The daily total of net all-wave radiation is always positive, showing that daytime gains are always larger than nighttime losses. During the 26-d period, the largest net all-wave irradiance gain $\left(524 \mathrm{~W} \mathrm{~m}^{-2}\right)$ was experienced at midday on the clear day of June 11 , while the largest loss $\left(-102 \mathrm{~W} \mathrm{~m}^{-2}\right)$ occurred just after sunset on the clear day of June 2 , although similar values occurred on other clear evenings. The 24 -h-mean gain was 107 , the mean daytime gain was 200 , and the mean nighttime loss was $-62 \mathrm{~W} \mathrm{~m}^{-2}$.

\subsection{Surface Energy Budget Terms}

Individual 30-min-average components of the surface energy balance over the 26-d period are shown in the lower panels of Figures 5.1a and 5.1b. Daily and daytime totals are shown in Table 5.1. To maintain a surface energy balance, the daytime radiative excess and the nighttime radiative deficit in the ecosystem must be balanced [see Equation (4.2)] by the nonradiative terms in the surface energy budget. These terms include the ground heat flux, the sensible heat flux, and the latent heat flux, which are discussed in the following sections.

\subsubsection{Ground Heat Flux}

The average ground heat flux during the $26-\mathrm{d}$ period is at the rate of $14 \mathrm{~W} \mathrm{~m}^{-2}$, with an average rate of $36 \mathrm{~W} \mathrm{~m}^{-2}$ during daytime and $-25 \mathrm{~W} \mathrm{~m}^{-2}$ during the shorter nighttime. Thus, the large radiative gains to the surface during daytime are partially countered by losses to the soil, and nighttime radiative losses from the surface are countered by an upward flux of heat from the soil. Because the mean ground heat flux is positive at the soil surface, and the temperature of the soil at a depth of, say, $1 \mathrm{~m}$, is expected to change only slowly with time, June is a time when soil heat flux convergence continues to warm the soil column from its winter minimum.

From Equation (4.2), it is apparent that the difference between the net all-wave and ground heat fluxes is equal in magnitude to the sum of the convective fluxes. The difference therefore represents the energy that is available for partitioning into the convective fluxes. This quantity has 
often been termed "available energy" by previous investigators. Ground heat flux totals are $18 \%$ of the net all-wave radiation totals during daytime, but are over $39 \%$ of the net radiation totals during nighttime. Thus, ground heat flux plays a significant nighttime role in the surface energy budget by supplying heat to the ecosystem to counteract the longwave losses.

\subsubsection{Sensible Heat Flux}

At Krebs Ranch, because of the generally dry ground and the resultant small values of ground heat flux and latent heat flux, much of the radiation excess during daytime is converted to sensible heat flux. The largest upward flux experienced during the 26-d period was $472 \mathrm{~W} \mathrm{~m}^{-2}$ at midday on the clear day of June 11. The downward sensible heat fluxes at night, which supply heat to the ecosystem and counterbalance the nighttime radiative losses, are typically at the rate of about $-40 \mathrm{~W} \mathrm{~m}^{-2}$. For the 26-d period, the daily average upward sensible heat flux is at the rate of $77 \mathrm{~W} \mathrm{~m}^{-2}$, with a daytime average of $141 \mathrm{~W} \mathrm{~m}^{-2}$.

\subsubsection{Latent Heat Flux}

The amount of latent heat flux depends on the type and amount of vegetation, the soil moisture, and the available energy. At Krebs Ranch, the vegetation was sparse and under water stress and the soil was generally dry, so latent heat flux makes up only a small part of the surface energy budget, except after rainstorms. The largest latent heat flux $\left(182 \mathrm{~W} \mathrm{~m}^{-2}\right)$ occurred during a day that followed a rainy period. Enhanced latent heat fluxes followed each rainy period. The 26-d average latent heat flux was $15 \mathrm{~W} \mathrm{~m}^{-2}$, with latent heat fluxes averaging $23 \mathrm{~W} \mathrm{~m}^{-2}$ during the day and $2 \mathrm{~W} \mathrm{~m}^{-2}$ during the night. Nighttime latent heat fluxes were generally small, with some nights having a small negative latent heat flux (indicating dewfall), and other nights having a small positive flux (indicating evaporation). Overall, $17 \%$ of the available energy was used to support latent heat flux, and $83 \%$ was used to support sensible heat flux, i.e., $\beta=4.9$.

Daily total evapotranspiration values for the experimental period can be calculated from the daily total latent heat fluxes using the formula

$$
\overline{\mathrm{E}}=\overline{\mathrm{Q}_{\mathrm{E}}}\left[\mathrm{L}_{0}-(\mathrm{dL} / \mathrm{dT}) \overline{\mathrm{T}}\right]
$$

where $\overline{\mathrm{Q}_{\mathrm{E}}}$ is the daily latent heat flux, $\mathrm{L}$ is the latent heat of vaporization of water at $0^{\circ} \mathrm{C}$ $\left(2.500 \mathrm{MJ} \mathrm{kg}^{-1}\right.$ ), dL/dT is $0.025 \mathrm{MJ} \mathrm{kg}^{-1} \mathrm{C}^{-1}$ and $\overline{\mathrm{T}}$ is the mean daily temperature in ${ }^{\circ} \mathrm{C}$.

The average daily evapotranspiration was about $0.5 \mathrm{~mm} \mathrm{~d}^{-1}$, and the total over the 26-d period was $13.3 \mathrm{~mm}$. Evapotranspiration was less than $0.03 \mathrm{~mm} \mathrm{~d}^{-1}$ on very dry days, but increased to 1-2 $\mathrm{mm} \mathrm{d}^{-1}$ following the rains of June 6 and June 19-20 and gradually decreased with time as the soil dried. A rain shower apparently occurred at the site on the evening of June 10 , as evidenced by an elevated value of latent heat flux on June 11 (Table 5.1). The Krebs Ranch site had no rain gauge, however, and no rain was recorded at surrounding climatological stations. 


\subsection{Cumulative Fluxes}

Cumulative fluxes of net all-wave irradiance, ground heat flux, sensible heat flux, and latent heat flux during the 26-d period are shown in Figure 6.1. The cumulative flux curves summarize the overall climatology of the site by indicating both the long-term and diurnal changes in individual surface heat flux terms, as well as allowing a comparison of the magnitude of the individual terms. As shown in Figure 6.1, the ecosystem in June is characterized by large excesses of net radiation, with large accumulations during daytime partially balanced by weak nighttime losses. These excesses support a large daytime upward sensible heat flux from the surface but, because of dry soil conditions and sparse vegetation, little latent heat flux. Nighttime latent heat fluxes are weak and variable in sign, indicating either dewfall or evaporation. Over the course of the month, the ecosystem gains significant amounts of heat through ground heat flux during daytime but partially reverses these gains at night.

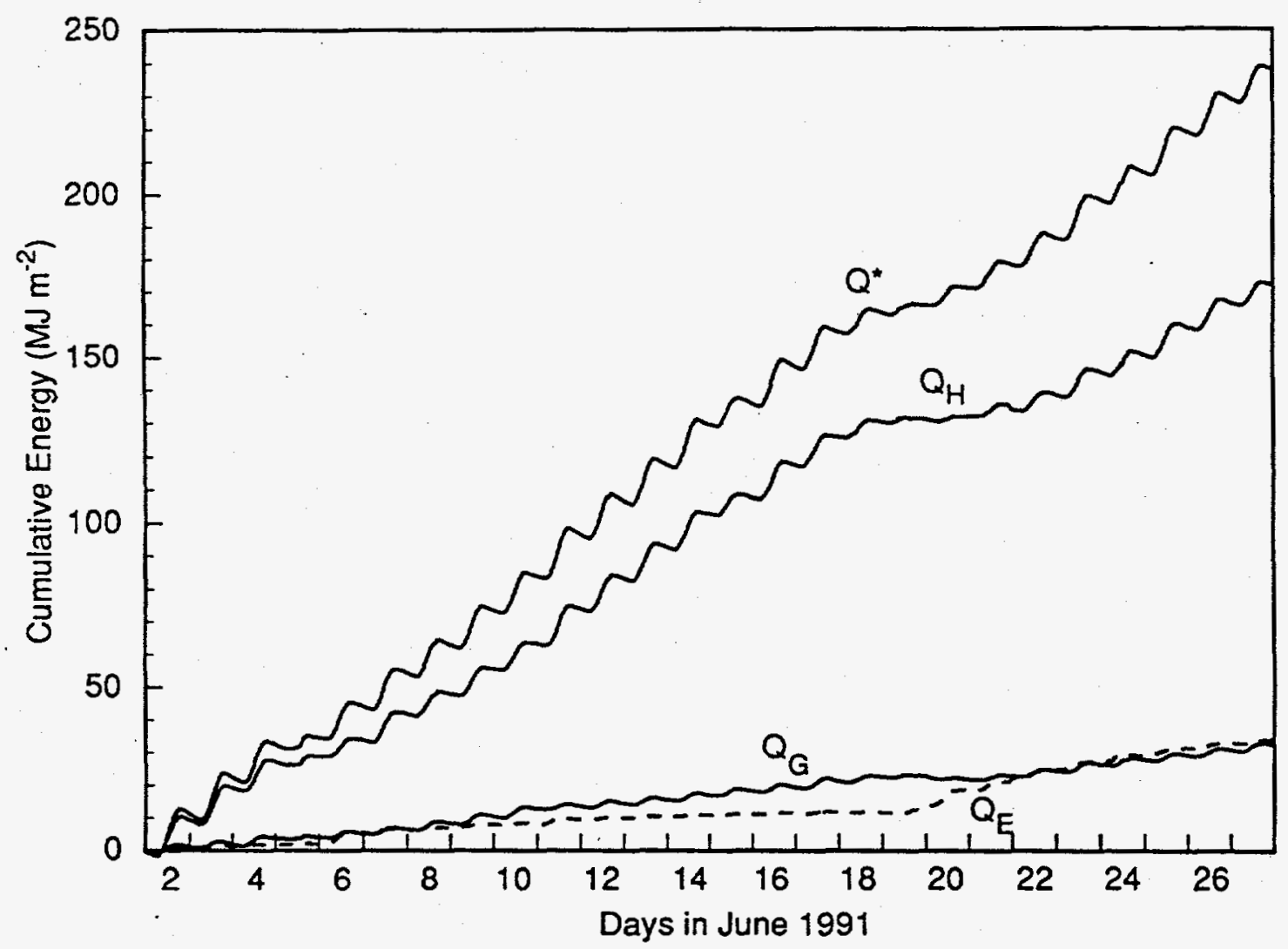

FIGURE 6.1. Cumulative Fluxes of Sensible Heat, Latent Heat, Soil Heat, and Net Radiation During the 26-d Period 


\subsection{Summary and Conclusions}

An experiment to measure the individual radiation and surface energy budget components was carried out for a steppe ecosystem in the Upper Columbia River Gorge from June 2 through June 27, 1991. This study is the first of its kind to report comprehensive long-term data from this location and climate setting.

On clear days, the ecosystem received from 71 to $76 \%$ of the theoretical extraterrestrial solar radiation. The albedo of the ecosystem over the $26-\mathrm{d}$ period varied from 0.17 to 0.21 . Daytime solar heating of the dry ground produced effective surface radiative temperatures of up to $58^{\circ} \mathrm{C}$.

For the 26-d experimental period as a whole, the radiation budget at the surface was characterized by an excess of daytime shortwave radiation gain, relative to the 24-h longwave loss, in the amount of $107 \mathrm{~W} \mathrm{~m}^{-2}$. The surface lost a 24-h average net heat flux to the soil in the amount of $14 \mathrm{~W} \mathrm{~m}^{-2}$. The net available energy at the surface $\left(\mathrm{Q}^{*}-\mathrm{Q}_{\mathrm{G}}=92 \mathrm{~W} \mathrm{~m}^{-2}\right)$ was used to evaporate water $\left(15 \mathrm{~W} \mathrm{~m}^{-2}\right)$ and to heat the atmosphere $\left(77 \mathrm{~W} \mathrm{~m}^{-2}\right)$. The net radiation, sensible heat flux, and ground heat flux generally reversed from day to night, but nighttime latent heat fluxes were small and variable in sign from night to night, indicating either dew fall or evapotranspiration. The mean Bowen ratio (sensible heat flux/latent heat flux) at this semiarid site was 4.9 . Only $17 \%$ of the available energy was used to support latent heat flux, with the remainder used to support sensible heat flux. Large differences in radiative and surface energy budget components occurred between clear and cloudy days.

Evapotranspiration for the 26-d period was $13.3 \mathrm{~mm}$. Daily evapotranspiration exceeded $2 \mathrm{~mm} \mathrm{~d}^{-1}$ during or immediately after rainy periods but was less than $0.03 \mathrm{~mm} \mathrm{~d} \mathrm{~d}^{-1}$ on very dry days. 


\subsection{References}

Albrecht, B., and S. K. Cox,. 1977. "Procedures for Improving Pyrgeometer Performance." J. Appl. Meteor. 16:188-197.

Bowen, I. S. 1926. "The Ratio of Heat Losses by Conduction and by Evaporation from Any Water Surface." Phys. Rev. 27:779-787.

Campbell Scientific, Inc. (CSI). 1988. CSI Bowen Ratio Instrumentation Instruction Manual. Revision 11/88, Logan, Utah.

de Vries, D. A. 1975. "Heat Transfer in Soils." In Heat and Mass Transfer in the Biosphere, eds. D. A. de Vries and N. H. Afgan, pp. 5-28. Scripta Book Co., Washington, D.C.

Doran, J. C., F. J. Barnes, R. L. Coulter, and T. L. Crawford. 1992. "A Field Study of the Effects of Inhomogeneities of Surface Sensible and Latent Heat Fluxes." Preprints, Third Symposium on Global Change Studies, January 5-10, 1992, Atlanta, Georgia. American Meteorological Society, Boston, Massachusetts.

Doran, J. C., F. J. Barnes, R. L. Coulter, T. L. Crawford, D. D. Baldocchi, D. R. Cook, D. Cooper, R. J. Dobosy, L. Fritschen, R. L. Hart, L. Hipps, J. M. Hubbe, W. Gao, R. R. Kirkham, K. E. Kunkel, T. J. Martin, T. J. Meyers, W. Porch, J. D. Shannon, W. J. Shaw, E. Swiatek, and C. D. Whiteman. 1993. "The Boardman Regional Flux Experiment." Bull. Amer. Meteor. Soc. 73:1785-1795.

Fritschen, L. J., and J. R. Simpson. 1989. "Surface Energy and Radiation Balance Systems: General Description and Improvements." J. Appl. Meteor. 28:680-689.

Hillel, D. 1982. Introduction to Soil Physics. Academic Press, San Diego, California, 364 pp.

Lowe, P. R. 1976. "An Approximating Polynomial for Computation of Saturation Vapor Pressure." J. Appl. Meteor. 16:100-103.

Miller, D. H. 1981. Energy at the Surface of the Earth. International Geophysics Series, Vol. 27, Academic press, $516 \mathrm{pp}$.

Oke, T. R. 1978. Boundary Layer Climates. John Wiley and Sons, New York, 372 pp.

Whiteman, C. D., and K. J. Allwine. 1986. "Extraterrestrial Solar Radiation on Inclined Surfaces." Environ. Software 1:164-169. 


\section{APPENDIX A}

Method for Estimating the Soil Volumetric Heat Capacity 


\section{APPENDIX A}

\section{Method for Estimating the Soil Volumetric Heat Capacity}

The soil volumetric heat capacity was calculated from the de Vries (1975) formula

$$
C_{s}=f_{m} C_{m}+f_{o} C_{o}+f_{w} C_{w}+f_{a} C_{a} \quad\left[M J m^{-3} K^{-1}\right]
$$

where $f$ represents the volume fraction, and $\mathrm{C}$ represents the volumetric heat capacity of the soil constituents, namely minerals (m), organic matter (o), water (w), and air (a). The last term of this equation, representing the heat capacity of the atmosphere is negligle when compared to the other terms. From this equation it is clear that the numerical value of $\mathrm{C}_{\mathrm{s}}$ is a function of soil moisture, which varied over the course of the experiment as a function of rainfall and evapotranspiration. Soil samples of $0.085 \mathrm{~m}$ depth were collected on June $1,5,12,19$, and 28 to determine how soil moisture varied with time. Soil water mass fractions were determined using standard gravimetric procedures (ASTM-D2216-80). The mineral fraction of the soil consisted of $26 \%$ sand, $61 \%$ silt, and $13 \%$ clay. Organic matter made up $3.3 \%$ of the soil by weight. Results of laboratory analyses of the soil samples are presented in Table A.1.

Soil constituent volume fractions and volumetric soil heat capacities for each of the soil samples are presented in Table A.2 using the assumption that the organic and mineral constituent densities were 1.3 and $2.65 \mathrm{~g} \mathrm{~cm}^{-3}$, as suggested by Hillel (1982).

TABLE A.1. Soil Sample Analyses

\begin{tabular}{||l|c|c|c|c||}
\hline \multicolumn{1}{|c|}{ Date, time } & $\begin{array}{c}\text { Soil bulk density } \\
\left(10^{3} \mathrm{~kg} \mathrm{~m}^{-3}\right)\end{array}$ & $\begin{array}{c}\text { \% water by } \\
\text { weight }\end{array}$ & $\begin{array}{c}\text { \% water by } \\
\text { volume }\end{array}$ & $\begin{array}{c}\text { \% organic } \\
\text { matter by weight }\end{array}$ \\
\hline \hline June 1, 1830 & 1.41 & 2.11 & 2.98 & 4.06 \\
\hline June 5, 1750 & 1.48 & 2.26 & 3.34 & 3.76 \\
\hline June 12,1600 & 1.48 & 1.67 & 2.47 & 2.67 \\
\hline June 19,1000 & 1.49 & 2.69 & 4.01 & 2.93 \\
\hline June 28, 1900 & 1.34 & 6.11 & 8.19 & 3.14 \\
\hline \hline Average & 1.44 & 2.97 & 4.20 & 3.31 \\
\hline
\end{tabular}


TABLE A.2. Soil Sample Volume Fractions and Volumetric Soil Heat Capacities

\begin{tabular}{|l|c|c|c|c|c|}
\hline \multicolumn{1}{|c|}{ Date, time } & $\mathrm{f}_{\mathrm{m}}$ & $\mathrm{f}_{\mathrm{o}}$ & $\mathrm{f}_{\mathrm{w}}$ & $\mathrm{f}_{\mathrm{a}}$ & $\mathrm{C}_{\mathrm{s}}\left(\mathrm{MJ} \mathrm{m}^{-3} \mathrm{~K}^{-1}\right)$ \\
\hline \hline June 1, 1830 & 0.5145 & 0.0358 & 0.0298 & 0.4199 & 1.2442 \\
\hline June 5, 1750 & 0.5401 & 0.0375 & 0.0334 & 0.3890 & 1.3147 \\
\hline June 12, 1600 & 0.5401 & 0.0375 & 0.0247 & 0.3977 & 1.2782 \\
\hline June 19, 1000 & 0.5437 & 0.0378 & 0.0401 & 0.3784 & 1.3508 \\
\hline June 28, 1900 & 0.4890 & 0.0340 & 0.0819 & 0.3951 & 1.4075 \\
\hline \hline Average & 0.5255 & 0.0365 & 0.0420 & 0.3960 & 1.3191 \\
\hline
\end{tabular}

assumptions: $r_{\mathrm{o}}=1.3 \mathrm{~g} \mathrm{~cm}^{-3}$ and $r_{\mathrm{m}}=2.65 \mathrm{~g} \mathrm{~cm}^{-3}$, organic matter mass fraction $=0.033$.

Linear interpolation between the five soil heat capacity values that were calculated from the measurements could have been used to estimate soil heat capacities at 30-min intervals during the entire 26 days; however, two rainy episodes occurred during this period and no soil heat capacity measurements were available for the rainy periods, so that such an interpolation would be in error during the rainy periods. Precipitation data were therefore used to provide improved estimates of the variation of soil heat capacities for the entire period.

Precipitation amounts were interpolated from daily measurements at Arlington, $\left(120.12^{\circ} \mathrm{W}\right.$, $\left.45.72^{\circ} \mathrm{N}\right)$ and Boardman, Oregon $\left(119.70^{\circ} \mathrm{W}, 45.83^{\circ} \mathrm{N}\right)$. See Figure 2.1 for the locations of these climatological stations. Arlington recorded 1.8,3.6, 27.7, and $0.3 \mathrm{~mm}$ of rain on June 6, 19, 20 and 21 , respectively; Boardman recorded 2.3 and $6.9 \mathrm{~mm}$ on June 6 and 20, respectively. After accounting for the different observation times at Arlington (0900 PST) and Boardman (1800 PST), we estimated precipitation at the Krebs site as $2.0,3.3,19.8$ and $0.2 \mathrm{~mm}$ on June 6, 19, 20 and 21 , respectively.

The volume fraction of water after rain in the upper $0.08 \mathrm{~m}$ of soil was estimated from the formula $f_{w a}=f_{w b}+V_{r} / V_{t}$, where $f_{w a}$ is the volume fraction of water after rain; $f_{w b}$ is the volume fraction of water before rain; $V_{r}$ is the volume of precipitation; and $V_{t}$ is the total volume of soil to a depth of $0.08 \mathrm{~m}$. To account for drainage from the $0.08-\mathrm{m}$ surface layer, the water volume fraction after rain was arbitrarily limited to half the porosity $\left(1-f_{0}-f_{m}\right)$. The air volume fraction after rain, assuming $f_{m}$ and $f_{o}$ are constant, is $f_{a a}=1-f_{m}-f_{o}-f_{w a}$, and $C_{s}$ (after rain) $=f_{m} C_{m}+f_{o} C_{o}+f_{w a}$ $\mathrm{C}_{\mathrm{w}}^{\prime}+\mathrm{f}_{\mathrm{aa}} \mathrm{C}_{\mathrm{a}}$.

The above equations, with the assumption that $C_{8}$ decays linearly over a $24-h$ period following rain as the soil drains and dries, were used to estimate the soil volumetric heat capacity as a function 
of time for the whole experimental period (Figure A.1) based on measured values of $C_{8}$ from Table A.2, assumed to be representative of conditions before the rain, and four values of $C_{\varepsilon}$ (after rain) as estimated from precipitation data. With the above assumptions, soil volumetric heat capacity varies from $1.3 \mathrm{MJ} \mathrm{m}^{-3} \mathrm{~K}^{-1}$ for very dry soil to more than $2.2 \mathrm{MJ} \mathrm{m}^{-3} \mathrm{~K}^{-1}$ for saturated soil after a heavy precipitation event.

A typical daytime (nighttime) value of $\mathrm{Q}_{\mathrm{G}}$ is about $36(-24) \mathrm{W} \mathrm{m}^{-2}$. The daytime value is made up of about equal contributions from $Q_{s}$ and $Q_{F}$, while the nighttime value is composed mainly of $Q_{s}$. When the soil is dry, a daytime (nighttime) error in $Q_{S}$ of $0.1 \mathrm{MJ} \mathrm{m}^{-3} \mathrm{~K}^{-1}$ would result in a $Q_{G}$ error of $1.4(1.8) \mathrm{W} \mathrm{m}^{-2}$, both errors being relatively small in comparison to other terms in the surface energy budget. The $C_{S}$ adjustment method in this appendix, however, should significantly improve ground heat flux estimations under moist soil conditions after rain. For example, if a $C_{s}$ value of 1.3 were used, rather than a post-rain value of $2.2 \mathrm{MJ} \mathrm{m}^{-3} \mathrm{~K}^{-1}$, the relative error in the $\mathrm{Q}_{\mathrm{s}}$ term could approach $70 \%$, producing typical $\mathrm{Q}_{\mathrm{G}}$ errors in the range from $10-20 \mathrm{~W} \mathrm{~m}^{-2}$.

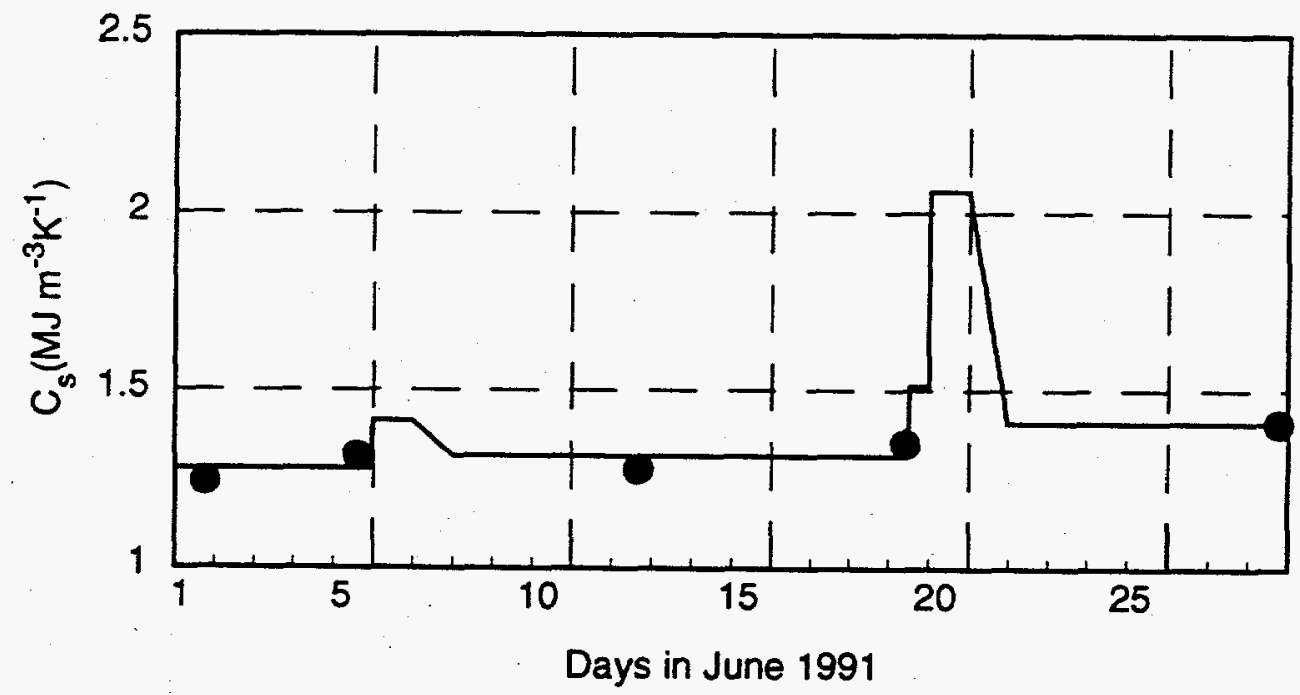

FIGURE A.1. The Soil Volumetric Heat Capacity Versus Time During the Experimental Period 


\section{Distribution}

\section{OFFSITE}

12 DOE/Office of Scientific and Technical Information

D. D. Baldocchi

NOAA/ATDD

$456 \mathrm{~S}$. Illinois Ave.

P.O. Box 2456

Oak Ridge, TN 37831-2456

L. Balick

U.S. Army Engineers, Waterways

Exp. Station

P.O. Box 631, Attn: Wesen

Vicksburg, MS 39180

F. J. Barnes

Los Alamos National Laboratory

Bikini Road

P.O. Box 1663

Los Alamos, NM 87545

D. R. Cook

Environmental Sciences Section

BEM/CER, Bldg. 203

Argonne National Laboratory

9700 S. Cass Avenue

Argonne, IL 60439

D. Cooper

Los Alamos National Laboratory

P.O. Box 1663, MS D-446

Los Alamos, NM 87544

R. L. Coulter

Atmospheric Physics Section

Argonne National Laboratory

Argonne, IL 60439
T. L. Crawford

NOAA/ATDD

$456 \mathrm{~S}$. Illinois Avenue

Oak Ridge, TN 37831

R. J. Dobosy

NOAA/ATDD

P.O. Box E

Oak Ridge, TN 37830

W. A. Dugas

Blackland Research Center

808 East Blackland Rd.

Temple, TX 76502

C. L. Fritschen

Radiation \& Energy Balance

Systems

P.O. Box 15512

Seattle, WA 98115-0512

L. J. Fritschen

8301 28th Ave. NE

Seattle, WA 98115

W. Gao

Argonne National Laboratory 9700 S. Cass Avenue

Argonne, IL 60439

R. L. Hart

Argonne National Laboratory

9700 S. Cass Avenue

Argonne, IL 60439

R. Hicks

Blackland Research Center 808 East Blackland Rd.

Temple, TX 76502

Distr.1 
L. Hipps

Utah State University

Logan, UT 84321

C. Krebs

Cecil Star Rte.

Ione, OR 97843

K. E. Kunkel

Illinois State Water Survey

2204 Griffith Drive

Champaign, IL 61820

W. P. Kustas

USDA Agricultural Research Service

Hydrology Laboratory

Beltsville, MD 20705

B. K. Lamb

Civil \& Environmental

Engineering Department

Washington State University

Pullman, WA 99164

F. Lamb

Eastern Oregon Farms

Boardman, OR 97818

T. J. Martin

Atmospheric Physics Section,

ER/Building 203

Argonne National Laboratory

Argonne, IL 60439

T. P. Meyers

NOAA/ATDD

$456 \mathrm{~S}$. Illinois Ave.

P.O. Box 2456

Oak Ridge, TN 37831-2456

Dr. William M. Porch

Mail Stop D401

Los Alamos National Laboratory

Los Alamos, NM 87545
J. D. Shannon

Argonne National Laboratory

9700 S. Cass Avenue

Argonne, IL 60439

D: I. Stannard

U.S. Geological Survey

P.O. Box 25046, MS 413

Denver, CO 80225

Dr. Marvin Wesely

Environmental Sciences Section

BEM/CER, BIdg. 203

Argonne National Laboratory

9700 South Cass Avenue

Argonne, IL 60439

\section{ONSITE}

DOE Richland Operations Office

D. D. Green

23 Pacific Northwest Laboratory

K. J. Allwine

X. Bian (10)

J. C. Doran

J. M. Hubbe

R. R. Kirkham

W. J. Shaw

C. D. Whiteman

Publishing Coordination

Technical Report Files (5)

\section{Routing}

R. M. Ecker

M. J. Graham

P. M. Irving

S. A. Rawson

P. C. Hays - last 